\title{
МЕХАНІЗМИ ПЕРЕКЛАДУ АНГЛІЙСЬКИХ ТЕРМІНІВ-НОВОУТВОРЕНЬ УКРАЇНСЬКОЮ МОВОЮ
}

Бондар Л. А. Механізми перекладу англійських термінів-новоутворень українською мовою.

У статті розглядаються умови і способи перекладу термінів з англійської мови українською. Ураховуючи комунікативні та функціональні особливості перекладу термінів, у цій статті розвивається типологія перекладу технічних неологізмів.

Ключові слова: переклад, науково-технічні терміни, неологізми, механізми.

Бондарь Л. А. Механизмы перевода английских терминов-новообразований на украинский язык.

В статье рассматриваются условия и способы перевода терминов с английского языка на украинский язык. Учитывая коммуникативные и функциональные особенности перевода терминов, в этой статье развивается типология перевода технических неологизмов.

Ключевые слова: перевод, научно-технические термины, неологизмы, механизмы. 
Bondar L. A. The mechanisms of translation of English new terms into Ukrainian.

The article focuses on the conditions and ways of translating new terms of the English language into Ukrainian. Taking into account the communicative and functional peculiarities of translating new terms, this article develops a typology of translating general technical neologisms.

Key words: translation, scientific and the technical of terms, neologisms, mechanisms.

У зв'язку з бурхливим розвитком техніки і збільшенням обсягу загальнотехнічної інформації піднялося практичне значення технічного перекладу. У наш час усе більше значення має інформація про останні досягнення зарубіжної науки і техніки. Це пояснюється тим, що переклад технічної термінології має стосунок до царини між мовознавством i технікою. Для грамотного перекладу замало одного практичного знання мови i спеціальності, 3 якою пов'язаний текст, що перекладають. Необхідно також володіти деякими елементарними знаннями в царині лінгвістики і теорії перекладу, оскільки у процесі перекладу вимагається самостійно проаналізувати термін-неологізм, відсутній у словниках, вибрати одне правильне слово 3 кількох значень іноземного терміна, а також самостійно спродукувати український термін, еквівалентний іноземному.

На сучасному етапі спостерігається новий підхід до дедалі уважнішого та детального вивчення термінів-новоутворень у різних галузях, що спричинено швидким зростанням їхньої кількості, адже поява нових реалій закономірно вимагає прискорення процесу номінації.

Процес збагачення словникового складу мови здійснюється різноманітними засобами. Ними можуть бути запозичення з інших мов, розширення значень уже наявного лексичного складу. Усі ці засоби достатньо продуктивні, однак найбільш виразними $є$ моделі словоскладання та афіксального утворення.

До факторів, що впливають на виникнення нових одиниць (і на всю систему словотворення загалом), належать: екстралінгвістичні фактори та соціальний прогрес, поширення інформаційного потоку і необхідність передати його 3 найменшими витратами часу і місця; лінгвістичні фактори - тенденція до мовної економії, прагнення до аналітичності.

Розвиток перекладознавства як науки сприяє розв'язанню нових завдань для створення механізмів перекладу. Науковці проводять дослідження у царині загальної теорії перекладу (Л. С. Бархударов, В. І. Карабан, Т. Р. Кияк, І. В. Корунець, Л. К. Латішев, Я. І. Рецкер, К. С. Серажим), теорії художнього перекладу (В. В. Коптілов, Т. Є. Некряч, М. О. Новікова), теорії машинного перекладу (О. М. Гон, Ю. Н. Марчук). Новітні дослідження української та англійської лексики кінця XX - початку XXI століття дозволяють виявити продуктивні й непродуктивні способи словотворення (I. В. Андрусяк, О. Л. Гармаш, І. П. Гусак， І. М. Думчак， Ю. А. Зацний， О. А. Стишов， О. М. Турчак, А. О. Худолій, А. В. Янков). Питання перекладу одиниць англійської мови, утворених різними способами словотворення, частково розглядалося в 
роботах К. А. Сльцова (переклад абревіатур), В.І.Карабана (переклад складних прикметників, прислівників на -ly, прикметників із суфіксом able). Проте увага лінгвістів до розгляду особливостей перекладу англійських термінів-новоутворень або неологізмів залишається недостатньою.

Актуальність окресленої проблеми зумовлена недостатнім дослідженням процесів формування нових слів науково-технічної терміносистеми, що відбувається на сучасному етапі розвитку. Вона пов'язується з необхідністю системного вивчення спеціальної англійської науково-технічної термінології як важливої частини лексичної підсистеми, що передбачає поряд із цілими словами також і їхні частини, словотвірні моделі і правила сполучення слів-термінів у синтагматичні послідовності для вираження конкретного номінативного завдання, у плані якомога повнішого іiі опису та виявлення всіх основних шляхів іiі формування, організації та функціонування в межах наукового дискурсу.

Об’єкт дослідження - терміни-неологізми англійської науково-технічної терміносистеми. Предмет дослідження - словотворчі моделі та механізми перекладу англійських термінів-неологізмів у науково-технічній сфері.

Мета статті: визначити умови й способи перекладу англомовних термінів-неологізмів, що вживаються в англійській науково-технічній терміносистемі та способи їх відтворення українською мовою. Поставлена мета потребує розв'язання таких завдань: розглянути особливості англійської терміносистеми; визначити основні особливості перекладу науково-технічної термінології з англійської мови українською.

Характерними особливостями науково-технічного стилю $\epsilon$ його інформативність, логічність, точність та об'єктивність, ясність та зрозумілість. Тексти, що належать до цього стилю, можуть виявляти відповідні ознаки більшою чи меншою мірою, у всіх таких текстів виявляється переважне використання мовних засобів, які допомагають задовольнити потреби спілкування. У царині лексики це передбачає використання науково-технічної термінології та спеціальної лексики.

Під поняттям «термін» розуміють емоційно нейтральне слово (словосполучення), що передає назву точно визначеного поняття, яке стосується тієї чи тієї галузі науки чи техніки. Термінологічна лексика дає змогу найбільш точно, чітко та економно передати зміст цього предмету та забезпечує правильне розуміння сутності визначеного питання.

Терміни можуть вступати в синонімічні відношення: одне і те саме поняття (чи предмет) іноді позначають різними словами: subscriber, user абонент; screen, shield - екран; trolley, truck, bogie, dolly - візок. Останні два явища - багатозначність та синонімія - заперечують функціонування терміна. Однак при описі конкретної предметної ситуації конкретної науково-технічної галузі, терміни не допускають їх неправильного перекладу [4, с. 28]. 
3-поміж розмаїття витлумачень поняття «переклад» вирізняється визначення, яке дав Я. І. Рецкер: «Переклад - це точне відтворення оригіналу засобами іншої мови зі збереженням єдності змісту і стилю» [7, с. 47]. Цим переклад відрізняється від простого відтворення, у якому можна передавати зміст іноземного оригіналу, випускаючи другорядні деталі і не турбуючись про збереження стилю. «Загальнонаукова та загальнотехнічна лексика складається зі слів, словосполучень, спеціальних утворень, спеціальних зворотів та кліше, які використовуються для вираження зв'язків та відношень між термінованими поняттями та об'єктами, а також для вираження якісних, кількісних та інших оцінних характеристик при диференціації та класифікації загальнонаукових та загальнотехнічних понять» [2, с. 213]. Наведемо приклади загальнотехнічних і загальнонаукових слів, які використовують у певних галузях для опису різноманітних процесів та явищ: to call up data from тетоry - визивати дані з пам'яті; to retrieve data - вибирати, відшукувати дані; to be alive - знаходитися під напругою; to draw current - випрямляти струм; to deenergize something вимикати напругу; to step ир voltage - підвищувати напругу.

Спеціальна теорія перекладу описує різні форми статистичної адаптації при перекладі текстів, що належать до певного функціонального стилю. Подібна адаптація зумовлена не тільки мовними відмінностями, про які вже йшла мова. Стилістична адаптація при перекладі може стати необхідною й у плані тих стилістичних ознак, що одночасно визначаються в аналогічних стилях вихідної мови й мови перекладу. «Одна і та сама стилістична риса може різною мірою виявлятися в кожній з мов та іiі присутність в оригіналі ще не означає, що вона може бути просто передана в тексті перекладу» [3, с. 164]. А тому стилістична адаптація - це один 3 механізмів перекладу, який необхідно враховувати.

Для науково-технічного стилю як в англійській, так в українській мові характерне прагнення до чіткості та точності викладення, характерні відмови від непрямих, описових позначень об'єктів, є типовим широке використання штампів та стереотипів спеціальної лексики. Однак більш детальний аналіз показує, що строгість у використанні термінів та звичних формулювань, в цілому, більш природна для українського науковотехнічного стилю, ніж для англійського. Тому перекладач нерідко відчуває себе зобов'язаним здійснити «стилістичне виправлення» оригіналу, вводить замість парафрази точний термін, пояснює, що конкретно мається на увазі, замінює авторський зворот більш звичним штампом. Одним 3 найпоширеніших випадків стилістичної адаптації в науково-технічному перекладі - це прагнення ввести в текст стилістичні чужорідні елементи. Наведемо приклад перекладу, де замість нестандартного опису в оригіналі використовуються стереотипні формулювання: We shall discover in the succeeding sections of this chapter that... (укр..: В наступних розділах иієї глави буде показано, що... ). 
О.С. Ахманова вважає, що для науково-технічного стилю характерна об'єктивно-описова манера викладу, коли відсутні емоційність та стилістична краса, але в англійських наукових текстах трапляються емоційні епітети, образні та фігуральні висловлювання, риторичні питання i т. ін. стилістичні прийоми, які забарвлюють мовлення. Такі порушення стилістичної єдності тексту менш природні для науково-технічних матеріалів в українській мові. Аналіз перекладів засвідчує, що перекладачі регулярно здійснюють стилістичну адаптацію тексту, який перекладають, не звертаючи увагу на емоційно-стилістичні елементи оригіналу, що здаються їм недоречними в «серйозному» науковому тексті.

Л. І. Павлова серед основних прийомів перекладу термінівсловосполучень розрізняє: 1) переклад за допомогою українських слів і виразів, які калькують слова і вирази англійської мови: single-arm semaphore - однокрилий семафор, single-row engine - однорядковий двигун, high-voltage switch - високовольтний вимикач, low-noise engine малогаласний двигун; 2) переклад за допомогою використання родового відмінка: direct current system - система постійного току, control-surface cable - трос керування; 3) переклад за допомогою використання різних прийменників: pressure oil gun - шприці для подачі масла під тиском, data processing equipment - обладнання для оброблення даних; 4) переклад одного 3 членів словосполучення групою пояснювальних слів: high aluminium cement - цемент 3 великим утриманням глинозему, analogue computer - рахунково-вирішальне обладнання непробивної діï, single-timelag servo - система спостереження з одним постійним часом, needle-beam underpining - підведення фундаменту 3 підтримуванням стіни за допомогою горизонтальних балок-підпорок; 5)переклад з зміною порядку компонентів атрибутивної групи: battery-charging motor generators мотор-генератори, підзаряджувальні батареї, automobile repair plant construction project - проект будівництва авторемонтного заводу [5, с. 20]. Ці основні прийоми також є тими механізмами перекладу, без яких неможливо подати точний аналог тих термінів, що аналізуються нами.

Значна кількість науково-технічних термінів у багатьох мовах утворюється через зміну значень слів загальнолітературної мови i термінів, запозичених з інших галузей науки і техніки. В українській мові це такі терміни, як крило літака, черевик гальма, в англійській мові: arm важіль, leg - нога літака, wing - крило літака.

Для термінотворення внаслідок зміни значення характерне те, що об'єкт термінологізації завжди має спільну ознаку з предметом чи явищем, назва якого використовується як термін. При їхньому перекладі слід пам'ятати, що ознака, яка береться для характеристики предмета i $\epsilon$ основною для перенесення назви, може бути випадковою, оскільки, на відміну від інших способів термінотворення, доводиться не продукувати термін, а вибирати наявне слово, значення якого відображає одна 3 кількох 
ознак, що репрезентує предмет загалом. Основні види термінотворення через зміну значення: назва за схожістю зовнішніх ознак, назва за схожістю функцій, назва за суміжністю понять, назва за аналогією понять [6, c. 20-22].

Побутують терміни, утворені за схожістю функцій (для окреслення поняття використовується слово, що позначає предмет, функції якого схожі з функціями об'єкта термінологізації). Наприклад: слово wing, як і в українській крило, послужило основою для створення терміна, що позначає одну з головних частин літака, призначену для створення підйомної сили при поступовому русі літака, слово leg (українське нога) сприяло появі терміна зі значенням «одна 3 підпор літака, що передбачає колесо, амортизатор і підкоси». В основі цього способу термінотворення лежить звичайна схожість чи аналогія між функцією, яка виконується людиною або частиною іiі тіла, i функцією для виконання якої призначається машина або механізм.

Наявні терміни, утворені за суміжністю понять - для вираження термінологізованого поняття використовується слово, яке так чи інакше пов'язується з вихідним. Наприклад: термін tare, як і український термін mара, служить для позначення не тільки самого упакування, але й ваги. Певна кількість технічних термінів утворена за допомогою синекдохи: engine означає двигун і паровоз, motor - мотор і автомобіль [6, с. 24].

Це уможливлює висновок про те, що для грамотного перекладу замало одного практичного знання мови та спеціальності, до якої мають стосунок тексти, що перекладаються. У статті проблеми термінології і переклад корелюється у плані порівняльного, статистичного і порівняльнотипологічного аналізу англійських термінологічних одиниць i ïx перекладацьких еквівалентів, виокремлених із англійських та українських спеціальних текстів. Труднощі, що виникають при перекладі термінів, пов'язані з недоліками, властивими наявним термінологічним системам, і 3 відсутністю системи механізмів перекладу. До найбільш важливих належать явища термінологічної синонімії та полісемії, що спонукає вдаватися до контекстуального перекладу, який передбачає: визначення терміна, що перекладається, за контекстом; вибір відповідного контекстуально- еквівалентного терміна.

Особливу увагу слід звернути на переклад вузькогалузевих термінівновоутворень. Їх варто перекладати в контекст, адже окремо взятий термін перекласти однозначно неможливо. Щоб ліквідувати помилки лінгвістиперекладачі мають досліджувати ті галузі техніки, до яких має стосунок перекладацька література, а техніки повинні не лише підвищувати практичне знання іноземної мови, але й оволодівати теорією перекладу науково-технічної термінології, вивчати питання словотворення, семантики, послуговуватися певними механізмами перекладу. 


\section{Література}

1. Корунець I. В. Теорія і практика перекладу (аспектний переклад) : [підручник] / І. В. Корунець. Вінниця : Нова книга, 2001. - 448 с.

2. Крупное В. Н. Курс перевода. Английский язык / В. Н. Крупное. - М. : Международные отношения, 1979. - 204c.

3. Кунцевич В. Н. Грамматические трудности перевода / В. Н. Кунцевич-Минск : МГЛУ, 1999. - 189с.

4. Носенко Н. А. Пособие по переводу научно-технической литературы / Н. А. Носенко. - М. : Высшая школа, 1999. - 349с.

5. Павлова Л. И. Курс перевода / Л.И. Павлова. - Минск. : МГЛИИЯ 1982. - 346с.

6. Пронина Р.Ф. Перевод английской научно-технической литературы / Р. Ф. Пронина. - М. : Высшая школа, 1986. - 175c.

7. Рецкер Я. И. Теория перевода и переводческая практика / Я. И. Рецкер. - М. : Международные отношения, 1974. - 216 с. 